ARTICLE HISTORY: Received: August 19, 2021 Accepted: October 12, 2021 Published: October 19, 2021

ВЛИЯНИЕ ПОЛИТИКИ ПЕРЕВОСПИТАНИЯ НА СМИ ГЕРМАНИИ.

Сметанова Анастасия Олеговна

\title{
THE INFLUENCE OF RE-EDUCATION ON THE GERMANY'S MEDIA OUTLETS
}

\author{
Smetanova Anastasia Olegovna
}

\begin{abstract}
Аннотация. В статье рассматриваются основные тенденции современных СМИ Германии, а также их соотношение с политикой перевоспитания, введенной в стране в период оккупации. Особое внимание уделяется влиянию политики перевоспитания на два влиятельных издания - «Der Ruf» и «Der Spiegel». C помощью сопоставления выделяются механизмы воздействия на прессу, а также выявляются особенности нынешнего
\end{abstract} облика «Der Spiegel».

Abstarct. The article deals with the main tendencies of modern Germany's media outlets and its correlation with reeducation policy implemented in the country during the occupation. Special attention is given to the high-powered editions - «Der Ruf» and «Der Spiegel». By this comparison we can allocate enforcement mechanisms on the press and distinguish features of the current appearance of «Der Spiegel».

Ключевые слова: Политика перевоспитания, послевоенная оккупация, либеральные ценности, социальный индивидуализм.

Key words: re-education policy, Germany's postwar occupation, liberal values, social individualism.

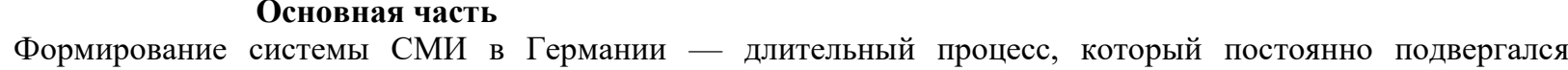
различному влиянию со стороны других государств. Как страна, побежденная во время Второй мировой войны, Германия была разделена на зоны оккупации - советскую (Советский Союз контролировал восточную часть), французскую, американскую и британскую (контролировали западную часть). В каждой части поделенной страны действовали свои законы, касающиеся выпуска печатных изданий, допустимой информации на их страницах.

На всей территории бывшего единого государства царил хаос - помимо полной экономической разрухи (города в руинах, почти абсолютное уничтожение транспортной системы, замирание коммунального хозяйства, непосильный финансовый долг), нация была морально искалечена — голод и физический, и духовный, страх, неизвестность перед будущим. Начался курс на демократизацию, денацификацию и демилитаризацию. Более того, со всех сторон осуществлялась пропаганда своих культурных традиций - каждая страна осознавала, что немецкое население нуждается в искусстве не меньше чем в питании, поэтому стремилась по-своему это использовать.

Новая система создавалась, фактически, с нуля. Именно поэтому газеты тех времен называют «газетами часа ноль». Несмотря на многие лишения, оккупационная политика внесла определенный вклад в развитие системы СМИ. Безусловно, национальная модель СМИ в качестве самостоятельной структуры начала более активно развиваться уже после предоставления ФРГ суверенитета. Однако многочисленные события из прошлого значительно повлияли на современный вид системы СМИ ФРГ.

Пройдя долгий путь, в Германии сформировались следующие «каноны»: региональная пресса, как и в Америке, занимает доминирующее положение по сравнению с национальной; бульварные газеты не получили широкого распространения, более того, некоторые исчезают с информационного рынка; коммерческое телевидение появилось только в середине 1980-х (в то время как первая передача была показана уже в 1929 году), в настоящее время существует совместно с общественно-правовым; в Германии наиболее жесткие законы, регулирующие рекламную деятельность (например, недопустима реклама «на живца» (Lockvogelwerbung), что означает рекламирование товара, количество которого не соответствует ожидаемому спросу, запас рекламируемого товара должен быть рассчитан на два рабочих дня).

Политика перевоспитания стала одним из катализаторов современных тенденций. Рассмотрим влияние этого процесса на примере таких медиагигантов, как «Der Ruf» и «Der Spiegel».

В декабре 1944 года в лагере Корнельского университета в Итаке была собрана группа антифашистски настроенных военнопленных, на чьих плечах лежала задача по созданию газеты для немецких военнопленных. Несмотря на то, что к тому времени существовало уже около 137 изданий, необходим был печатный орган, который бы транслировал идеи политики «перевоспитания», в то же время соответствовал интересам военнопленных. 
Так, в 1945 г. в Форт Кэрней вышло издание «Der Ruf», что в переводе с немецкого означает «Призыв». Газета просуществовала недолгий промежуток времени, всего с марта 1945 по апрель 1946 гг. Именно вокруг этого издания сплотились современные писатели и публицисты США (Вальтер Манцен, Ганс Вернер, Альфред Андерш и др.), которые впоследствии сформировали фундамент «Группы 47».

Активное участие в создании программы будущей газеты принимал Вальтер Шёнштедт. Совместно с другими участниками были разработаны следующие принципы: «Новая газета призвана побудить ее будущих читателей к совместным ответственным размышлениям и призвать их к участию в текущих событиях. Газета должна призывать к выходу из изолированности лагеря для военнопленных к внешней жизни, давать ответы многим сомневающимся и надеющимся голосам, беспокоящимся о мирном построении будущего»1. Так, именно поэтому ее название - «Призыв». Основная цель газеты - возрождение демократического мышления для восстановления после крушения национал-социализма.

Для того, чтобы преодолеть возможное недоверие к американской прессе, газета преднамеренно следовала стандартам основных крупных немецких журналов. Также для создания особого восприятия, тональность издания была близка к газетам нацисткой Германии. Ведь даже сами авторы долгое время находились в такой языковой среде, поэтому тон трудно было изменить сиюминутно. Несмотря на то, что «Der Ruf» издавали в основном непрофессионалы (за исключением некоторых лиц), издание вскоре добилось невероятного успеха: в марте 1945 года газета вышла тиражом в 10000 экземпляров, а через год количество увеличилось в восемь раз.

В основном состав редакции формировался из военнопленных, которые придерживались социалистических или коммунистических взглядов. Так, Вальтер Шёнштедт сам в прошлом был членом КПГ. На страницах газеты поначалу главенствовали следующие ориентиры: знакомство с американской демократией, «отлучение» от фашистских ценностей, избежание открытой пропаганды. До того, как вышел специальный номер, посвященный разоблачению политики «Третьего Рейха», на страницах газеты не использовались такие слова, как «фашизм», «нацизм» и др. И если в апрельском номере подписи под фотографиями, изображающими жителей Веймара, которых привели в концлагерь для того, чтобы стать свидетелями того сотворенного ужаса, содержали более нейтральную оценку («потрясенный немецкий народ видит истинное лицо нацизма») 2 , то в майском номере газеты звучали уже следующие мотивы: о «чудовищных преступлениях, совершенных в Бухенвальде»3. Однако такая «игра слов» подразумевала и некоторые риски в потере читателей. Вначале как правые, так и левые относились к изданию отрицательно, что было вызвано из-за того, что журнал не мог определиться чью позицию принимать.

Можно выделить три этапа развития журнала. Первый период заключался в концентрации сил, привлечении единомышленников, формировании общего подхода к проблемам времени. Второй период поиск ответа на самый волнующий вопрос - истоки и причины фашизма. Также затрагивалась тема будущей Германии. В статьях содержится много неконкретных размышлений, создается впечатления ухода от действительности. В третьем периоде наблюдается стремление редакции к построению собственной политики издания. Именно на этом этапе начинается конфронтация с американской военной администрацией, так как некоторые принципы политики «перевоспитания» отчуждаются редакцией. Рихтер и Манцер особенно резко возражали против публикации «антинемецких» статей. Ощутив все ужасы войны, Рихтер отказывался ассоциировать войну, нацистскую жестокость с мирным населением Германии. А оккупационный режим воспринимался им как полная несправедливость.

В последних номерах журнала уже поднимались свободные и дерзкие размышления о предоставлении Германии политической самостоятельности, равноправного участия в решении европейских вопросов, где Германия бы выступала как посредник между Европой и Западом.

Весной 1946 года, когда все военнопленные вернулись из США на свою родину, издание прекратило существование. Некоторое время спустя, уже с обновленной концепцией и программой, издание вновь было открыто, но уже не военнопленными, а свободными литературными деятелями.

«Der Spiegel» сквозь века - как политика перевоспитания повлияла на современный вид издания.

B противовес «Der Ruf» с его изначальной политикой, основанной на перевоспитании немцев, приведем историю возникновения и «летопись» первых годов существования влиятельного издания «Der Spiegel».

Это иллюстрированный журнал, который был основан в 1947 году. Его основатель, Рудольф Аугштайн, был бессменным издателем, образованным журналистом и писателем. Несмотря на то, что в британской зоне оккупации также был ориентир на смену нравственных устоев немецкого общества, методы контроля за прессой сильно отличались от инструментов и принципов союзников. Так, уже с 1945 года на территории британской зоны оккупации было разрешено создание политических изданий.

1 Е. Зачевский. Указ.Соч. С. 90

2 Der Ruf (USA) (1.6.1945)

3 Der Ruf (USA) (15.5.1945) 
В отличие от первых более сдержанных номеров «Der Ruf», в издании сразу задается тон — борьба с высокомерием оккупационных властей, наглостью чиновников, коррумпированностью вышестоящих. Журнал был инструментом демократии для Рудольфа Аугштайна, он пытался любым возможным способом отстоять права ущемленных. В 1949 г. впервые он получил обвинение в суде за клевету (распространение ложной информации). В журнале была опубликована статья, утверждавшая, что во время обыска в доме бывшего министра сельского хозяйства были найдены мясные консервы. Однако вскоре редактор был оправдан, но конфликты с властью не прекратились.

«Политика перевоспитания» дала толчок к развитию журнала в определенном направлении, а именно против новой сложившейся системы оккупационных властей. Позиция журнала не соответствовала общественно-политическим установкам, принятым военной администрацией. Именно поэтому журнал развивался будто в своем собственном направлении, выделяясь на фоне остальных изданий.

Даже сегодня, в то время как в основном главный ориентир CMИ - честность, объективность, «Der Spiegel» опирается на следующие принципы, формируя собственную повестку: права человека (социальный индивидуализм), толерантность и личная свобода4.

Соответственно, к «политике перевоспитания» редакция журнала относилась крайне негативно: «В этом конфликте, - говорит Бунгенстаб, чтобы научить народ демократии недемократическими средствами», американцы предпочли сами быть хорошими демократами и «держать железный кулак в секрете как можно дольше». Так что «все осталось как было» (Бунгенстаб) — как было во времена Веймара»5.

Сегодня журнал представляет собой крупное информационно-политическое издание, публикации которого сопровождаются многочисленными деталями и подробностями, переполнены различными средствами авторской выразительности. Со стороны критиков существуют самые различные суждения: журнал информирует только с одной стороны произошедшего, публикует недостоверные факты, личные характеристики лиц использует в качестве главного средства.

Свободный тон издания зародился во времена, когда пресса Германии находилась под тяжелейшим колпаком политики «перевоспитания». Но несмотря на железные оковы, журнал выдержал стойкие испытания временем и до сих пор продолжает информировать население, но уже в совершенно иных масштабах.

\section{Заключение}

Нельзя отрицать тот факт, что американская политика «перевоспитания» сыграла важную роль в демократизации немецкого общества и способствовала культурному и духовному перерождению Германии.

Однако такая политика, основной целью которой было приобщение немецкого народа к иным духовным ценностям не была воплощена в той мере, в которой намеревались ее провести американские власти. В своей статье ганноверский политолог Карл-Эрнст Бунгеншта пишет о том, что главная причина провала «великой миссии» состояла в том, что американцы почти без точных методов и без конкретных соображений попытались изменить духовные ценности целой нации. Самое главное, что для воплощения задуманного не хватило попросту миссионеров.

Стремление насильно преподнести высокие идеалы демократии, неотъемлемым элементом чего стало внушение о том, что в самой нации кроется значительных изъян, привело не к полному преображению общества, а к появлению комплексов, что впоследствии стало одной из причин утраты чувства национальной идентичности. Безусловно, нельзя утверждать, что вина полностью лежит на плечах тех, кто способствовал введению данной политики. Однако попытка «перевоспитания» сильно повлияла как на отличительные черты системы немецких СМИ, так и в целом на духовное состояние нации.

Почему сегодня важно изучать то, что было несколько десятков лет назад? Только путем тщательного анализа исторического контекста, мы можем сформировать свое общее представление о статусе издания, о его направлении и важнейших редакционных стандартах. Только через политику «перевоспитания» мы сможем более обширно изучить сегодняшних медиа гигантов.

\section{Список литературы:}

Вороненкова Г.Ф. Путь длиною в пять столетий: от рукописного листка до информационного общества. Национальное своеобразие средств массовой информации Германии. СПб., 2000.

Галактионов Ю.В. «Духовная жизнь и культура послевоенной Германии (1945-1949 гг.) // Уральский вестник международных исследований. 2005. No 3. С. 108-116. // Режим доступа: https://elar.urfu.ru/bitstream/10995/4716/2/uvmi3-2005-06.pdf /

Прутцков Г.В. История Зарубежной журналистики 1929-2011. М., 2011

4 Nichts interessiert den Menschen so sehr wie der Mensch. Darum sollten alle SPIEGEL - Geschichten einen hohen menschlichen Bezug haben. 5 https://www.spiegel.de/politik/grosse-mission-a-028f6b3b-0002-0001-0000-000043278734 
Greenberg E. Germany's Postwar Re-education and Its Weimar Intellectual Roots // Journal of Contemporary History Vol. 46, No. 1 (JANUARY 2011), pp. 10-32

DER SPIEGEL. 1971. No 17 // https://www.spiegel.de/spiegel/print/index-1971-17.html /

Der Ruf (USA) 1945. No 1.6.

Der Ruf (USA) 1945. No 15.5

Greenberg E. Germany's Postwar Re-education and Its Weimar Intellectual Roots // Journal of Contemporary History Vol. 46, No. 1 (JANUARY 2011), pp. 10-32 // https://www.jstor.org/stable/25764607?seq=5\#metadata_info_tab_contents /

Kriegsgefangenen. Faksimile-Ausgabe. Schutzumschlag. München: Saur Verlag, 1986.

Vinz, K. "Zur Geschichte des RUF - Zeitung der deutschen Kriegsgefabgenen in USA." Der Ruf. Zeitung der deutschen

\section{References:}

Galaktionov U.V. Spiritual life and culture of post-war Germany (1945-1949) // Ural'skiy vestnik mezhdunarodnykh issledovaniy. 2005.No 3.P. 108-116.

Greenberg E. Germany's Postwar Re-education and Its Weimar Intellectual Roots // Journal of Contemporary History Vol. 46, No. 1 (JANUARY 2011), pp. 10-32

DER SPIEGEL. 1971. No 17 // https://www.spiegel.de/spiegel/print/index-1971-17.html /

Der Ruf (USA) 1945. No 1.6.

Der Ruf (USA) 1945. No 15.5

Greenberg E. Germany's Postwar Re-education and Its Weimar Intellectual Roots // Journal of Contemporary History Vol. 46, No. 1 (JANUARY 2011), pp. 10-32 // https://www.jstor.org/stable/25764607?seq=5\#metadata_info_tab_contents /

Kriegsgefangenen. Faksimile-Ausgabe. Schutzumschlag. München: Saur Verlag, 1986.

Vinz, K. "Zur Geschichte des RUF - Zeitung der deutschen Kriegsgefabgenen in USA." Der Ruf. Zeitung der deutschen

Pruttskov G.V. History of Foreign Journalism 1929-2011. M.: 2011.

Voronenkova, G.F. A Five-Century Path: From Handwritten Sheet to Information Society. The national identity of the German media. SPb. : 2000. 